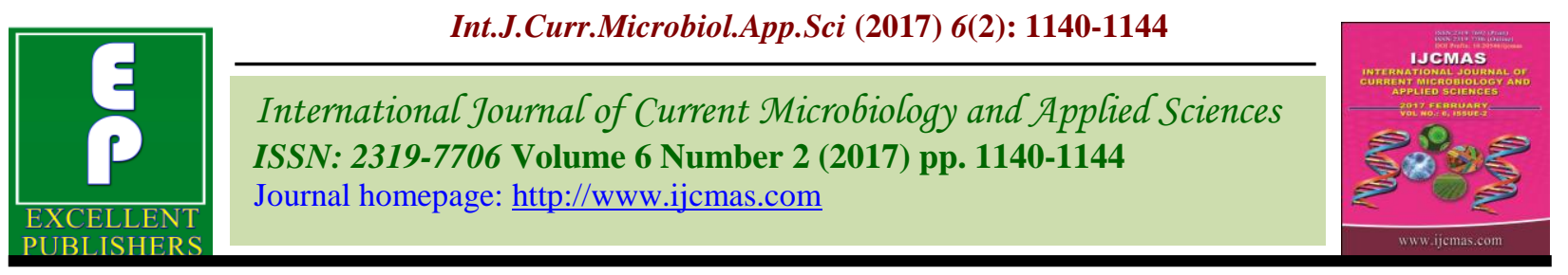

Original Research Article

http://dx.doi.org/10.20546/ijcmas.2017.602.129

\title{
Seed Mycoflora of Lablab purpureus $\mathbf{L}$.
}

\section{D.Sai kumari* and Neetisaxena}

Mycology and Plant Pathology Lab, Department of Botany, University College for women, Koti, Osmania University, Hyderabad, Telangana, India

*Corresponding author

\section{A B S T R A C T}

\begin{tabular}{|l|}
\hline K e y w o r d s \\
Mycoflora, \\
Hyacinth bean, \\
Agar plate method, \\
Protein, \\
Mycotoxins \\
\hline Article Info \\
\hline $\begin{array}{l}\text { Accepted: } \\
\text { 20 January } 2017 \\
\text { Available Online: } \\
\text { 10 February } 2017\end{array}$ \\
\hline
\end{tabular}

In the present study attempts have been made on the isolation and identification of fungi in order to study the mycoflora responsible to reduce the seed quality, longevity and vigor in the pulse of Hyacinth bean. Lablab purpureus $L$. is an annual plant that grows in poorly - drained soils belongs to the family Fabaceae. It contains high amount of protein, vitamins and minerals. Fungal cultures were isolated by using blotter and agar plate methods.22 fungal species and 14 genera were isolated. Aspergillus spp, Alternaria spp, Curvularia spp, Fusarium spp, Rhizopus spp, Mucor spp were dominant species. These species were found that they cause considerable amount of loss, spoilage of storage grains and also produce mycotoxins.

\section{Introduction}

Seeds of legumes or pulses form an important source of dietary proteins they provide essential amino acids to our predominantly vegetarian population (Mohd shaker et al., 2010). Legumes also relatively rich in two essential micronutrients namely iron and calcium. Increasing population pressure, fast depletion of natural resources, poverty and low agricultural production are some of the problems faced by the developing countries. It is well documented that the developing countries do not produce enough food and of the right nutritional quality to meet daily needs (Kamatchi Kala et al., 2010). To prevalent food shortage, attention is currently being focused on the exploitation of lesser known and non-traditional plant resources (Bresssani, 1975). Exploitation of underutilized wild legumes is an important approach to combat the protein- malnutrition in developing countries. Food legumes source of protein, carbohydrates, minerals and vitamins. Being rich in protein, carbohydrates, calorific value, fiber, and vitamins, legumes constitute staple food in many countries.

Lablab purpureusis grown as a pulse crop in Africa, Asia and the Caribbean. It is also consumed as a green vegetable (Maas et al., 2010). It is may suffer from low yields when grown as a main cash crop, and suggest that it 
is more popular in home gardens and mixedcropping schemes. Seeds contain 20to $28 \%$ crude protein (Cooke et al., 2005) and contain large amounts of various vitamins and minerals.

Protein isolate from the bean can be used as a food additive. It has medicinal properties used in the Philippines and China as a stimulant, reduces flatulence, stimulates digestion and used as an anti-spamodic (Stuart, 2011). In Namibia, the roots have been used to treat heart conditions (Pennacchio et al., 2010). It is used as a nitrogen- fixing green manure to improve soil quality.

The crops have been reported to suffer from various types of disease and majority of them are known to be caused by fungi which are seed- born in nature. Several seed- born fungi cause considerable loss in the seed content, among them degradation of starch, lipids, proteins in legumes due to seed-borne fungi which resulted in decreased quality of the seeds.

In the present investigation an attempt has been made to study the Isolation and identification of seed- borne mycoflora of Lablab purpureus seeds during storage condition.

\section{Materials and Methods}

Seed samples: Seed samples collected from the field and market places from the Indurthi village, Kharimnagar district, Telangan, India. Seed samples from different sources of the pulse crop was stored individually preserved in cloth bags at room temperature during the studies.

\section{Detection of seed mycoflora}

Isolation of seed mycoflora was done by blotter method De Tempe, (1953) and agar plate method by Muskett, (1948).

\section{Standard blotter paper method}

This is very simple, most convenient and efficient of all the incubation methods. Doyer (1938), De Tempe was first to adopt blotter paper method in seed health management. Three layers of sterile white blotter papers of $8.5 \mathrm{~cm}$ diameter were soaked in sterile distilled water and were placed in presterilized Petri plates of $90 \mathrm{~mm}$ diameter.

Ten seeds of test sample per Petri plates were then placed at equal distance on moist blotter. 100 seeds were used in each experiment. The plates were incubated at $28^{0} \pm 2^{0} \mathrm{C}$ under diurnal conditions. On seventh day of incubation, seeds were first examined under electron microscope for determining the various fungal growths. The identification and further confirmation of seed borne fungi was made by preparing slides of fungi (Rathod $e t$ al., 2012).

\section{Agar plate method}

In Northern Ireland, Musket (1948) first used this method for seed health management. In this method, pre-sterilized Petri plates were poured with $15 \mathrm{ml}$ of autoclaved Potato Dextrose Agar (PDA). On cooling the medium, ten seeds per plate of the sample to be studied were equidistantly placed aseptically. Incubation and other details of the study were same as described for blotter paper method.

\section{Results and Discussion}

Contaminated seeds can often result in poor germination and poor seedling vigor, resulting in an un-healthy crop. Healthy seed is the foundation of healthy plant a necessary condition for good yields. Field fungus associated with cause deterioration of seed quality, affects viability and reduces germination (Neeti saxena et al., 2015; Tripati Agarwal et al., 2011). 
Twenty two fungal species, 14 genera were identified in two varieties of Lablab purpureus seeds, such as Alternaria alternata, Aspergillus niger, Aspergillus flavus, Aspergillus fumigatus, Aspergillus nidulans, Aspergillus terreus, Aspergillus tenuis, Cladosporium spp, Curvularia lunata, Colletotrichum dematium, Cephalosporium acromonium, Fusarium oxysporum, Fusarium moniliformae, Macrophomin aphaseolina, Mucor racemosus, Mucorindicus, Nigrospora oryzae, Pencillium citrinum, Phomabetae,
Rhizoctonia solani, Rhizopus nigricans, Rhizopus stolonifera (Table 1). Most of the storage fungi isolated from the market variety than the Field variety. The difference is may be due to the age of the seed, seed type, and with the individual seed in the seed lot (Neetisaxena et al., 2015). Storage fungi were present in low percentage in freshly harvest seed samples and became dominant as the storage period increased. Storage fungi require high osmatic pressure and no water (Manoharachary and Kunwar, 2006).

Table.1 Fungi identified from field and market seed varieties

\begin{tabular}{|l|l|l|l|l|l|}
\hline \multirow{2}{*}{ S. No } & \multirow{2}{*}{ Name of the Fungus } & \multicolumn{2}{|l|}{ Field variety } & \multicolumn{2}{l|}{ Market variety } \\
\cline { 3 - 6 } & & BP.M & AGP.M & BP.M & AGP.M \\
\hline 1. & Alternariaalternate & + & + & + & + \\
\hline 2. & Aspergillus niger & + & + & + & + \\
\hline 3. & Aspergillus flavus & + & + & + & + \\
\hline 4. & Aspergillus fumigatus & + & + & + & + \\
\hline 5. & Aspergillus nidulans & + & + & + & + \\
\hline 6. & Aspergillus terreus & + & + & + & + \\
\hline 7. & Aspergillus tenuis & + & + & + & + \\
\hline 8. & Cladosporiumspp & - & + & - & + \\
\hline 9. & Curvularialunata & - & + & - & + \\
\hline 10. & Colletotrichumdematium & - & + & - & + \\
\hline 11. & Cephalosporiumacromonium & - & + & + & + \\
\hline 12 & Fusarium oxysporum & + & + & + & + \\
\hline 13. & Fusarium moniliformae & + & + & + & + \\
\hline 14. & Macrophominaphaseolina & + & + & + & + \\
\hline 15. & Mucorracemosus & + & + & + & + \\
\hline 16. & Mucorindicus & - & + & + & + \\
\hline 17. & Nigrosporaoryzae & - & + & + & + \\
\hline 18. & Pencilliumcitrinum & - & + & - & + \\
\hline 19. & Phomabetae & + & + & + & + \\
\hline 20. & Rhizoctoniasolani & - & + & + & + \\
\hline 21. & Rhizopusnigricans & + & + & + & + \\
\hline 22. & Rhizopusstolonifera & + & + & + & + \\
\hline
\end{tabular}

BP.M- Blotter paper method; AGP.M- Agarplate method

The present study has demonstrated that seeds of Lablab purpureus frequently carry a number of pathogenic fungi which can cause serious diseases in the field. Storage conditions in most parts of India are very conducive for mold invasion, proliferation and elaboration of mycotoxins (Girish and Goyal, 1986). Alternaria, Aspergillus, Cheatomium, Cladosporium, Curvularia associated with the seeds and these are 
important seed borne fungi, Isolated from the both methods. The same results observed by Deo and Guptha, 2003; Mohdshekhar et al., 2010). Seeds were adversely affected by the species of Aspergillus, Alternaria, and Fusarium species. Reddy, 1982 reported in many pulses. Rhizopus, Cephalosporium spp, Pencillium were observed in both methods (Jain and Patel et al., 2004). Fusarium and Macrophomina were predominant in pulses. Chilkurind Giri, 2014; Kandare Ashok Sadhu (2014) observed and isolated them on the seeds of green gram.

More number of fungi were recovered in the agar plate than blotter method, this gives an idea that nutrients from the media might play an important role in initiation of growth of fungi on pulses also the media composition was more favorable than blotter method

In conclusion the fungi which were isolated from the blotter plate and agar plate method are seed- borne and cause deleterious effects on the seeds of stored grains. Both storage fungi and certain molds were observed. Which plays and important role in to reduce viability, longevity, quality of the seeds of both Field variety and Market variety of Indurthi village, Kharimnagar, Telangana, India.

\section{Acknowledgement}

I would like thank to UGC for providing the NON-NET fellowship through the Department of Botany, University College of Science, Osmania University, Hyderabad Telangana state, India.

\section{References}

Bresssani, R. 1975. Legumes in human diet and how they might be improved. In Polyphenols in cereals and legumes: Ed, Milner: IDRE, Ottawa, Canada.
Chilkuri Ashwini and Giri, G.K. 2014. Detection and transmission of seedborne mycoflora in Green gram and effect of different fungicides. Int. $J$. Adv. Res., 5(5): 1118-1186.

Cook, B.G., B.C. Pengelly, S.D. Brown, J.L. Donnelly et al., 2005. Tropical forages: an interactive selection tool. Lablab purpureus. CSIRO, DPI\&F (Qld),CIAT, and ILRI, Brisbane, Australia.

De Tempe. 1953. The blotter method of seed health testing. Proc. Int. Seed test Assoc., 28: 133-151.

Deo, P.P, \& Gupta, S. 2003. Screening of aflatoxigenic strains of Aspergillus falvus associated with the seeds of some pulses. Acta Botanica, 9: 331333.

Doyer, L.C. 1938. Manual for the determination of seed- borne disease. Wageningen, netherland: International seed testing Association, p.59.

Girish, G.H. and Goyal, R.K. 1986. Prevention and control of mycotoxins in food grains in India. Bull. Grain Tech., 24: 157-177.

Jain. J.P. and Patel, J.N. 2004. Seed mycoflora of gour their role in emergence and vigour of seedling efficacy of fungicides. Indian Phytopath., 22(2): 245-250.

Kamatchi Kala, B., and V.R. Mohan. 2010. Chemical composition and Nutritional Evaluation of Lesser known Pulses of the Genus, Mucana. Adv. Biores., Vol (2) December 2010: 105-116.

Kandhare Ashok Sadhu. 2014. Seed -borne fungi and their effect on seed health of Green gram. Bioscience Discovery, 5 (2): 251-255.

Maass, B.L., M.R. Knox, S.C. Venkatesha, T.T. Angessa, S. Ramme, and B.C. Pegellly. 2010. Lablab purpureus- a crop lost for Africa? Trop. Plant Biol., 
3(3): 123-135.doi: 10.1007/s 12042010-9046-1.

Manoharachary, C. \& I.K. Kunwar. 2006. Seed borne fungal pathogens of Soya bean. J. Basic Appl. Mycol., 5(I\&II): 18.

Mohd Shaker, Momin R.K. and Seema Hashmi. 2010. Isolation and identification of some pulses mycoflora. Vol: 3 (2) July- December 2010: ISSN 0974-0678.

Muskett, A.E. 1948. Technique for the examination of seeds for the presence of seed borne fungi. Trans. Brit. Mycol. Soc., 39: 74-83.

NeetiSaxena, S.K., Shivarani and M. Deepika. 2015. Biodeterioration of Soyabean (Glycine max L.) seeds during storage by Fungi. Int., J. Curr. Microbiol. App. Sci., 4(6): 1118-1126.

Pennacchio, M., L.V. Jefferson, and K. Havens. 2010. Uses and abuses of plant- derived smoke: its ethano-botany as hallucinogen, perfume, incens, and medicine. Oxford Univ. Press Inc., New York.

Rathod, L.R., M.D. Jadhav, S.K. Mane, S.M. Muley, P.S. Deshmukh. 2012. Seed borne mycoflora of legume seeds. International J. Adv. Biotechnol. Res., 3( I): 530-532.

Reddy, A.S., Reddy, S.M. 1982. Influence of seed moisture on fungal succession on seeds of sesamum. Seed Res., 10(2): 120-124.

Stuart, G. 2011. Stuartxchange-Philippine alternative medicine.

Tripati Agarwal, Abhiniti Malhothra and P.C. Trivedi. 2011. Fungi associated with chickpea, lentil and Black gram seeds of Rajasthan. Int. J. Pharma and biosci., Vol/ issue 4/ Oct-Dec 2011.

\section{How to cite this article:}

Sai KumaraI, D. and Neetisaxena. 2017. Seed Mycoflora of Lablab purpureus L. Int.J.Curr.Microbiol.App.Sci. 6(2): 1140-1144.

doi: http://dx.doi.org/10.20546/ijcmas.2017.602.129 